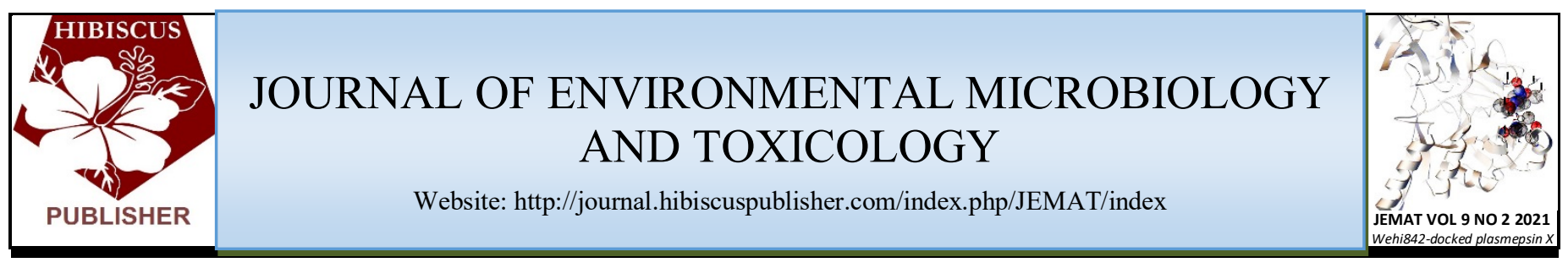

\title{
Isothermal Modelling of the Adsorption of Chromium onto Calcium Alginate Nanoparticles
}

\author{
Bilal Ibrahim Dan-Iya ${ }^{1,2}$ and M.Y. Shukor ${ }^{1 *}$ \\ ${ }^{1}$ Department of Biochemistry, Faculty of Biotechnology and Biomolecular Sciences, Universiti Putra Malaysia, \\ 43400 UPM Serdang, Selangor, Malaysia. \\ ${ }^{2}$ College of Health Sciences and Technology Kano, Nigeria. \\ *Corresponding author: \\ Yunus Shukor, \\ Department of Biochemistry, \\ Faculty of Biotechnology and Biomolecular Sciences, \\ Universiti Putra Malaysia, \\ 43400 UPM Serdang, \\ Selangor, \\ Malaysia. \\ Email: mohdyunus@upm.edu.my/yunus.upm@gmail.com
}

\section{HISTORY}

Received: $15^{\text {th }}$ Oct 2021

Received in revised form: $24^{\text {th }}$ Nov 2021

Accepted: $22^{\text {nd }}$ Dec 2021

\section{KEYWORDS}

Biosorption

Chromium

Isotherm

Calcium alginate nanoparticles

Langmuir

\begin{abstract}
Because of its extensive usage in industrial applications such as leather tanning, metallurgy, electroplating, and refractory materials, chromium is one of the most dangerous trace elements introduced into surface and ground waters. The sorption isotherm of chromium sorption onto calcium alginate nanoparticles were analyzed using ten models - Henry, Langmuir, DubininRadushkevich, Freundlich, BET, Toth, Sips, Fritz-Schlunder IV, Baudu and Fritz-Schlunder V, and fitted using non-linear regression. Only the Toth and Fritz-Schlunder V models were unable to fit the data. Statistical analysis based on root-mean-square error (RMSE), adjusted coefficient of determination $\left(\operatorname{adj} R^{2}\right)$, bias factor $(\mathrm{BF})$, accuracy factor $(\mathrm{AF})$, corrected AICc (Akaike Information Criterion), BIC and HQC showed that the Langmuir model was the best model in terms of overall best criteria. The calculated evidence ratio was 7 with an AICc probability value of 0.87 indicating that the best model was at least 7 times better than the nearest best model, which was Freundlich. The calculated Langmuir parameters $q_{m L}$ value of $79.174 \mathrm{mg} / \mathrm{g}(95 \%$ confidence interval from 50.702 to 107.646$)$ and $b_{L}$ value of $0.332 \mathrm{~L} / \mathrm{mg}(95 \%$ confidence interval from 0.294 to 0.371 ) is not much different from the linearized published work for the $q_{m L}$ value of $145 \mathrm{mg} / \mathrm{g}$ but lower than the $b_{L}$ value of $0.34 \mathrm{~L} / \mathrm{mg}$. The nonlinear regression method allows for the parameter values to be represented in the $95 \%$ confidence interval range which can better allow comparison with published results.
\end{abstract}

\section{INTRODUCTION}

Consumption of polluted water by residents of low-income neighbourhoods results in illness. Biological and inorganic wastes, sediments, radioactive materials, effluents and sewages, as well as heavy metals, are the principal sources of water pollution. Heavy metals are a major source of concern among these pollutants because of their toxicity, bioaccumulation, persistence, and non-biodegradability [1-5]. Another source of concern is the release of metals from large-scale mining operations, which results in high concentrations of heavy metals in rivers. Researchers are constantly on the lookout for innovative methods of removing harmful metal ions from wastewater. Chromium has long been a source of environmental concern when it comes to wastewater treatment [3,6-9]. An inadequate supply of chromium can have detrimental consequences for the metabolism of both plants and animals. The contamination of chromium by industrial sources, on the other hand, is becoming increasingly serious. A range of sources, including the dye and pigment industries, wood preservation, electroplating, and leather tanning, can contribute to chromium contamination in wastewater. A total of over 80 percent of the country's tanneries employs chrome tanning techniques. It is estimated that the great majority of these facilities discharge untreated sewage into the environment.

Currently, new chemicals are being released into the environment as a result of current industrial activity patterns, which is interfering with the regular flow of materials [10-14]. Heavy metals are defined as metals with a density more than or equal to $5 \mathrm{~g} / \mathrm{mL}$ and are classified as such. Today's world is plagued by heavy metal contamination of water, which is a huge problem. The absorption of heavy metals by organisms is also found to be more dependent on the concentration of free metal 
ions in solution than the concentration of total metal in solution, as has been discovered previously. Since improved correlations between metal absorption and the concentration of free metal ions or labile metals have been established, the bioavailability and toxicity of heavy metals are now mostly governed by the number of heavy metals present in free metal ions. They are dangerous to human health because of their nonbiodegradability and high concentrations of heavy metals. World Health Organization (WHO) has identified a number of metals as the most significant dangers to human health in the modern era. These include cadmium, chromium, cobalt, copper, lead, nickel, mercury, zinc, arsenic, and tin. The major three extremely harmful metals are mercury, cadmium, and lead in terms of neurotoxicity [15-19].

It is only the trivalent and hexavalent oxidation states of chromium that are of concern to the environment, and they can be found in a range of oxidation levels ranging from +2 to +6 . When present in high amounts, the trivalent chromium, Cr (III), is a necessary trace element in living organisms, but it can be hazardous to health when combined with organic compounds, blocking specific metalloenzyme systems. Chromium in the cryochromate $\left(\mathrm{CrO}_{4}^{2-}\right)$ and dichromate $\left(\mathrm{Cr}_{2} \mathrm{O}_{7}{ }^{2-}\right)$ forms is more toxic than chromium in other valence states [20]. When selecting an adsorbent for the removal of dangerous metal ions, it is important to consider both traditional and non-conventional materials [9,21-24] including nanomaterials. The sorption of chromium ions onto nanoparticles have been attempted before using silicon and iron nanoparticles [25-27].

The precise assignment of biosorption kinetics and isotherms is critical for understanding the process of biosorption in these species. In many cases, the literature reports a linearized version of an obviously nonlinear curve of these data. Nonlinear data linearization distorts the data's error structure, making it more difficult to assess uncertainty, which is often displayed as a 95 percent confidence interval range [28]. In this study the published data from a chromium sorption onto calcium alginate nanoparticle is remodeled with several more isotherms models (Table 1) and then regressed using nonlinear regression method and assessment of the best mode was carried out using various error function analysis.

\section{METHODS}

\section{Data acquisition and fitting}

Data from Figure 1 from a published work [23] were digitized using the software Webplotdigitizer 2.5 [39]. The data were then nonlinearly regressed using the curve-fitting software CurveExpert Professional software (Version 1.6). Digitization using this software has been acknowledged for its reliability $[40,41]$.

\section{Statistical analysis}

A battery of statistical discriminatory tests such as corrected AICc (Akaike Information Criterion), Bayesian Information Criterion (BIC), Hannan and Quinn's Criterion (HQ), RootMean-Square Error (RMSE), bias factor (BF), accuracy factor (AF) and adjusted coefficient of determination $\left(R^{2}\right)$ were utilized in this work.
Table 1. Isotherm models utilized in this study.

\begin{tabular}{|c|c|c|}
\hline Model & Formula & $\begin{array}{l}\text { Refe- } \\
\text { rences }\end{array}$ \\
\hline Henry's law & $q_{e}=H C_{e}$ & [29] \\
\hline $\begin{array}{l}\text { Langmuir } \\
\text { isotherm }\end{array}$ & $q_{e}=\frac{q_{m L} b_{L} C_{e}}{1+b_{L} C_{e}}$ & [30] \\
\hline $\begin{array}{l}\text { Freundlich } \\
\text { isotherm }\end{array}$ & $q_{e}=K_{F} C_{e}^{\frac{1}{n_{F}}}$ & [31] \\
\hline $\begin{array}{l}\text { Dubinin- } \\
\text { Radushkevich } \\
\text { isotherm }\end{array}$ & $q_{e}=q_{m D R} \exp \left\{-K_{D R}\left[R T \ln \left(1+\frac{1}{C_{e}}\right)\right]^{2}\right\}$ & {$[32,33]$} \\
\hline Sips isotherm & $q_{e}=\frac{K_{s} q_{m s} C_{e}^{\frac{1}{n_{S}}}}{1+K_{S} C_{e}^{\frac{1}{n_{S}}}}$ & [34] \\
\hline Toth isotherm & $q_{e}=\frac{q_{m T} C_{e}}{\left(K_{T}+C_{e}^{n_{T}}\right)^{n_{T}}}$ & [35] \\
\hline BET isotherm & $q_{e}=\frac{q_{m B E T} \alpha_{B E T} C_{e}}{\left(1-\beta_{B E T} C_{e}\right)\left(1-\beta_{B E T} C_{e}+\alpha_{B E T} C_{e}\right)}$ & {$[36]$} \\
\hline $\begin{array}{l}\text { Baudu } \\
\text { isotherm }\end{array}$ & $q_{e}=\frac{q_{m B} b_{B} C_{e}^{(1+x+y)}}{1+b_{B} C_{e}^{(1+x)}}$ & [37] \\
\hline $\begin{array}{l}\text { Fritz- } \\
\text { Schlunder-IV } \\
\text { isotherm }\end{array}$ & $q_{e}=\frac{A_{F S} C_{e}^{a_{F S}}}{1+B_{F S} C_{e}^{b_{F S}}}$ & [38] \\
\hline $\begin{array}{l}\text { Fritz- } \\
\text { Schlunder-V } \\
\text { isotherm }\end{array}$ & $q_{e}=\frac{q_{m F S 5} K_{1} C_{e}^{\alpha_{F S}}}{1+K_{2} C_{e}^{\beta_{F S}}}$ & [38] \\
\hline
\end{tabular}

The RMSE was calculated according to Eq. (1), [28], and smaller number of parameters is expected to give a smaller RMSE values. $n$ is the number of experimental data, $O b_{i}$ and $P d_{i}$ are the experimental and predicted data while $p$ is the number of parameters.

$R M S E=\sqrt{\frac{\sum_{i=1}^{n}\left(P d_{i}-O b_{i}\right)^{2}}{n-p}}$

As $R^{2}$ or the coefficient of determination ignores the number of parameters in a model, the adjusted $R^{2}$ is utilized to overcome this issue. In the equation (Eqns. 2 and 3), the total variance of the y-variable is denoted by $S_{y}^{2}$ while RMS is the Residual Mean Square.

Adjusted $\left(R^{2}\right)=1-\frac{R M S}{s_{Y}^{2}}$

Adjusted $\left(R^{2}\right)=1-\frac{\left(1-R^{2}\right)(n-1)}{(n-p-1)}$ 
The AICc is calculated as follows (Eqn. 4), where $p$ signifies the quantity of parameters and $n$ signify the quantity of data points. To handle data having a high number of parameters or a smaller number of values corrected Akaike information criterion (AICc) is utilized [42].A model with a smaller value of AICc is deemed likely more correct [42]. The Akaike Information Criterion (AIC) is based on the information theory. It balances between the goodness of fit of a particular model and the complexity of a model [43].

$A I C c=2 p+n \ln \left(\frac{R S S}{n}\right)+2(p+1)+\frac{2(p+1)(p+2)}{n-p-2}$

(Eqn. 4)

Aside from AICc, Bayesian Information Criterion (BIC) (Eqn. 5) is another statistical method that is based on information theory. This error function penalizes the number of parameters more strongly than AIC [44].

$B I C=n \cdot \ln \frac{R S S}{n}+k \cdot \ln (n)$

(Eqn. 5)

A further error function method based on the information theory is the Hannan-Quinn information criterion (HQC) (Eqn. 6). The HQC is strongly consistent unlike AIC due to the $\ln \ln n$ term in the equation [42];

$H Q C=n \times \ln \frac{R S S}{n}+2 \times k \times \ln (\ln n)$

(Eqn. 6)

Further error function analysis that originates from the work of Ross [45] are the Accuracy Factor (AF) and Bias Factor (BF). These error functions test the statistical evaluation of models for the goodness-of-fit but do not penalize for number of parameter (Eqns. 7 and 8).

Bias factor $=10^{\left(\sum_{i=1}^{n} \log \frac{\left(P d_{i} / O b_{i}\right)}{n}\right)}$

Accuracy factor $=10^{\left(\sum_{i=1}^{n} \log \frac{\left|\left(P d_{i} / O b_{i}\right)\right|}{n}\right)}$

(Eqn. 8)

Another error function analysis is the evidence ratio regarding the difference between the two lowest AICc values (Eqn. 9), where if it is the same, then each model will have an equal chance of being true. If the difference in AICc scores is 6.0, model A has a $95 \%$ chance of being correct, making it $20(95 / 5)$ times more likely than model B to be correct [28].

$P_{A}=\frac{e^{0.5 \Delta}}{1+e^{0.5 \Delta}}$

(Eqn. 9)

\section{RESULTS AND DISCUSSION}

The equilibrium data from [23] was analyzed using ten modelsHenry, Langmuir, Dubinin-Radushkevich, Freundlich, BET, Toth, Sips, Fritz-Schlunder IV, Baudu and Fritz-Schlunder V, and fitted using non-linear regression. Only the Toth and FrtzSchlunder V models cannot fit the data (Figs. 1-7) Statistical analysis based on root-mean-square error (RMSE), adjusted coefficient of determination $\left(\operatorname{adj} R^{2}\right)$, bias factor (BF), accuracy factor (AF), corrected AICc (Akaike Information Criterion), BIC and HQC showed that the Langmuir model was the best model in terms of overall best criteria (Table 2). The calculated evidence ratio was 7 with an AICc probability value of 0.87 indicating that the best model was at least 7 times better than the nearest best model, which is Freundlich. The calculated Langmuir parameters $q_{m L}$ value of $79.174 \mathrm{mg} / \mathrm{g}(95 \%$ confidence interval from 50.702 to 107.646$)$ and $b_{L}$ value of $0.332 \mathrm{~L} / \mathrm{mg}$ (95\% confidence interval from 0.294 to 0.371 ) is not much different from the linearized published work for the $q_{m L}$ value of $145 \mathrm{mg} / \mathrm{g}$ but lower than the $b_{L}$ value of $0.34 \mathrm{~L} / \mathrm{mg}$ [23].



Fig. 1. Biosorption isotherm of chromium onto calcium alginate nanoparticles as modelled using the Henry model.

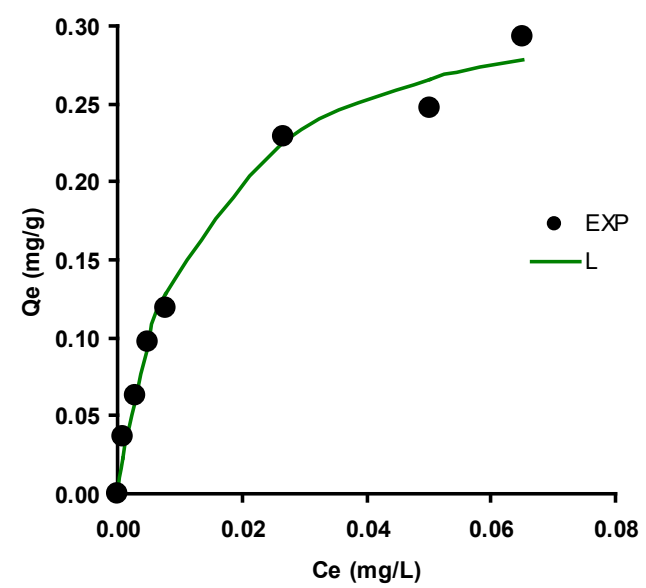

Fig. 2. Biosorption isotherm of chromium onto calcium alginate nanoparticles as modelled using the Langmuir model. 


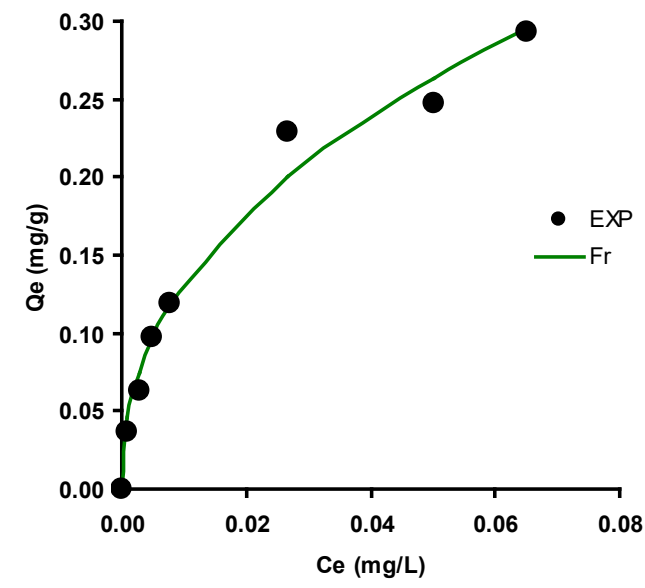

Fig. 3. Biosorption isotherm of chromium onto calcium alginate nanoparticles as modelled using the Freundlich model.

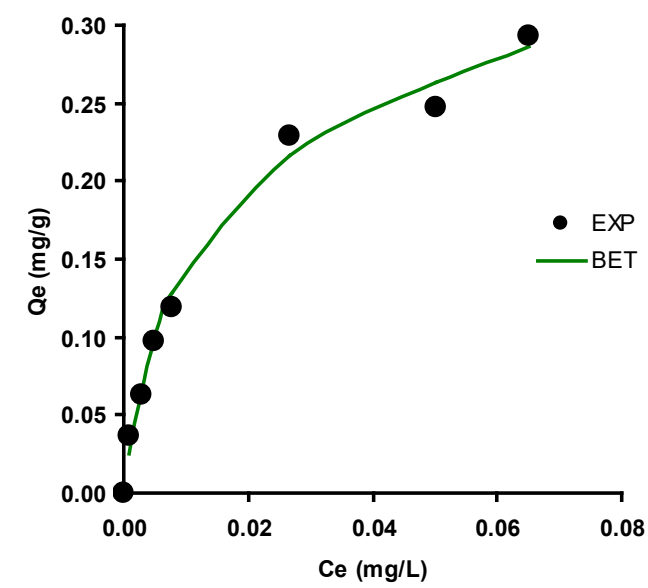

Fig. 4. Biosorption isotherm of chromium onto calcium alginate nanoparticles as modelled using the BET model.

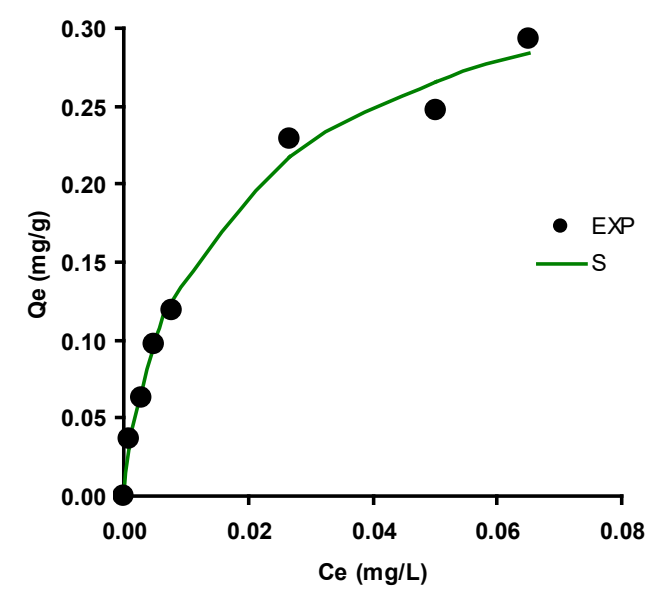

Fig. 5. Biosorption isotherm of chromium onto calcium alginate nanoparticles as modelled using the SIPs model.

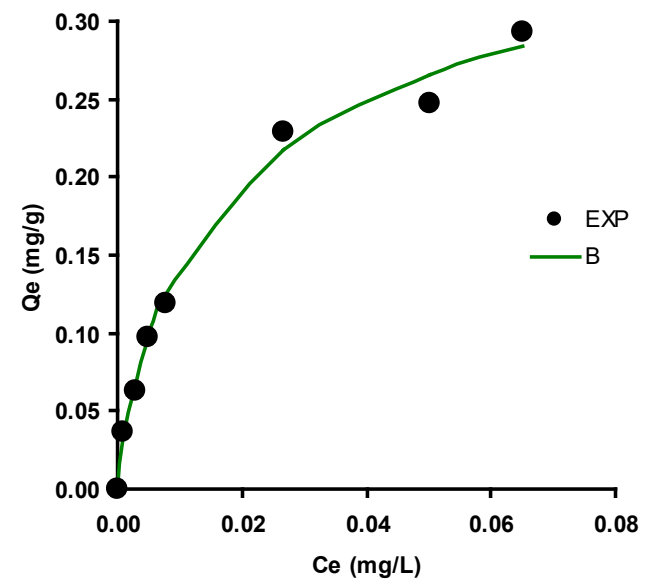

Fig. 6. Biosorption isotherm of chromium onto calcium alginate nanoparticles as modelled using the Baudu model.

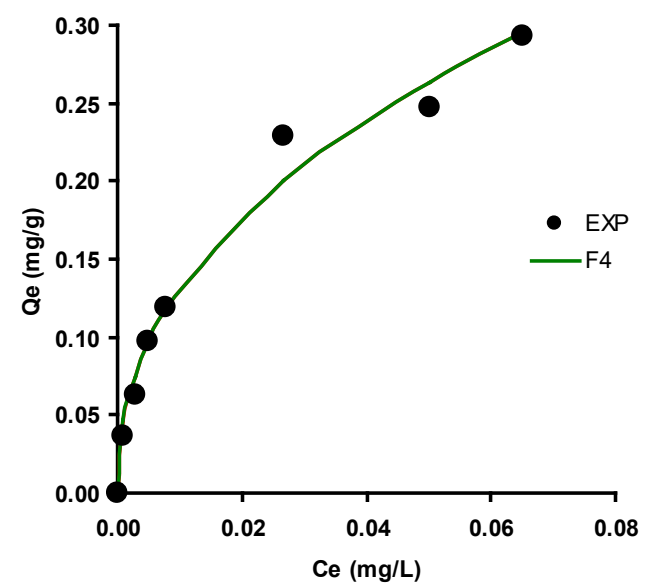

Fig. 7. Biosorption isotherm of chromium onto calcium alginate nanoparticles as modelled using the Fritz-Schlunder IV model.

Table 2. Error function analysis for the fitting of the isotherm of chromium onto calcium alginate nanoparticles.

\begin{tabular}{llllllllll}
\hline Model & $p$ RMSE & adR2 & \multicolumn{2}{c}{ AICc } & BIC & HQC & \multicolumn{2}{c}{ BF } & AF \\
\hline Henry & 1 & 0.06 & 0.76 & -37.74 & -44.06 & -44.68 & 0.46 & 2.28 \\
Langmuir & 2 & 0.01 & 0.99 & -57.41 & -69.26 & -70.49 & 0.94 & 1.10 \\
Freundlich & 2 & 0.01 & 0.98 & -53.66 & -65.50 & -66.73 & 1.04 & 1.08 \\
BET & 3 & 0.01 & 0.99 & -47.92 & -69.02 & -70.86 & 0.96 & 1.08 \\
Sips & 3 & 0.01 & 0.99 & -48.49 & -69.59 & -71.43 & 0.99 & 1.05 \\
Baudu & 4 & 0.01 & 0.98 & -27.85 & -67.54 & -70.00 & 0.99 & 1.05 \\
F4 & 4 & 0.02 & 0.96 & -21.66 & -61.35 & -63.81 & 1.04 & 1.08
\end{tabular}

Note:

RMSE Root mean Square Error

$p$ no of parameters

$\begin{array}{ll}p & \text { no of parameters } \\ \mathrm{adR}^{2} & \text { Adjusted Coefficient of determination }\end{array}$

$\mathrm{BF}$ Bias factor

AF Accuracy factor

$\begin{array}{ll}\text { AF } & \text { Accuracy factor } \\ \text { AICc } & \text { Adjusted Akaike Information Criterio }\end{array}$

AICc Adjusted Akaike Information Criter
BIC Bayesian Information Criterion

$\begin{array}{ll}\text { BIC } & \text { Bayesian Information Criterion } \\ \text { HQC } & \text { Hannan-Quinn information criterion }\end{array}$ 
A broad range of sorbents, including nanomaterials with various forms of coating and chemical synthesis method as well as other approaches, can be used to remove trace elements from freshwater [46-51]. Nanomaterials, which are defined as materials and structures with at least from 1-100 nm offer different mechanical, optical, magnetic, and chemical properties with respect to particles and macroscopic surfaces of similar consistency. These qualities are extremely dependent on the shape, size, surface char-acteristics, and inner structure of the particle, and they are unique from those of macroscopic surfaces and particles of a comparable composition.

The sorption processes of nanomaterials are also reliant on the physical-chemical characteristics of the fluid in which they are absorbed or desorption, which should be kept in mind [5254]. When used as sorbents for the removal of toxic elements from wastewater, nanomaterials must meet a number of requirements, including being nontoxic, having high sorption capacities, being selective to low concentrations of contaminants, being easy to remove the sorbed contaminant from the surface of the nanomaterial, and being recyclable. It has been investigated whether detrimental trace elements can be removed from aqueous solutions using a variety of nanomaterials, including carbon nanotubes and carbon-based material composite materials like graphene, nanometals or metal oxides, and polymeric sorbents, which have all met these requirements to date [55-58].

The Langmuir isotherm is among the most cited best isothermal models to govern biosorption of xenobiotics including chromium sorption [21,26,59-77]. In a more specific detail, the Langmuir models for chromium biosorption is the best model in $\mathrm{Cr}$ (VI) and Fe (III) removal using Cajanus cajan husk [65] $(\mathrm{Cr}(\mathrm{VI}))$ from aqueous solutions onto activated carbons (AC). $[78,79]$, biosorption and bioreduction of $\mathrm{Cr}(\mathrm{VI})$ by locally isolated Cr-resistant bacteria [80] and agricultural wastes [8]. Both the Langmuir and Freundlich model were found to best fit on Chromium (VI) adsorption on sulfonated lignite [81]. Also both Langmuir and the Temkin model best fit the adsorption of chromium (VI) by ethylenediamine-modified cross-linked magnetic chitosan resin [82].

The maximum sorption uptake capacity reported in this study is higher than several published works on nanoparticles (NP) sorption of chromium such as $\mathrm{Sn}$ (II) oxy-hydroxides NP at $31 \mathrm{mg} / \mathrm{g}$ [83], multi-walled carbon nanotubes at $12.61 \mathrm{mg} / \mathrm{g}$ [84] and lower than in several works such as nano zirconium oxide $187 \mathrm{mg} / \mathrm{g}$ [85] and Lagerstroemia speciosa bark (LB) embedded magnetic nanoparticles $739.7 \mathrm{mg} / \mathrm{g}$ [86].

\section{CONCLUSION}

In conclusion, the absorption kinetics data of biosorption isotherm on the biosorption of chromium onto calcium alginate nanoparticles has been successfully analyzed using modelled according to various models ranging from one to five parameters models and fitted using non-linear regression. Statistical analysis based on root-mean-square error (RMSE), adjusted coefficient of determination $\left(\operatorname{adj} R^{2}\right)$, bias factor $(\mathrm{BF})$, accuracy factor $(\mathrm{AF})$, $\mathrm{BIC}, \mathrm{HQC}$ and corrected AICc (Akaike Information Criterion) showed that the Langmuir model is the best model in terms of overall statistics. The calculated Langmuir parameters differ slightly from the linearized method. The nonlinear regression method allows for the parameter values to be represented in the $95 \%$ confidence interval range which can better allow comparison with published results.

\section{REFERENCES}

1. Berger $\mathrm{M}$, Löffler $\mathrm{D}$, Ternes $\mathrm{T}$, Heininger $\mathrm{P}$, Ricking $\mathrm{M}$, Schwarzbauer J. Hexachlorocyclohexane derivatives in industrial waste and samples from a contaminated riverine system. Chemosphere. 2016;150:219-26.

2. Yang $\mathrm{C}, \mathrm{Yu} \mathrm{H}$, Jiang $\mathrm{H}$, Qiao $\mathrm{C}$, Liu $\mathrm{R}$. An engineered microorganism can simultaneously detoxify cadmium, chlorpyrifos, and $\gamma$-hexachlorocyclohexane. J Basic Microbiol. 2016;56(7):820-6.

3. Cheng J, Gao J, Zhang J, Yuan W, Yan S, Zhou J, et al. Optimization of Hexavalent Chromium Biosorption by Shewanella putrefaciens Using the Box-Behnken Design. Water Air Soil Pollut. 2021 Feb 22;232(3):92.

4. Tiimub B, Agyenta J, Azure A, Tiimob G, Osei-Bonsu R. Effectiveness of fluoride decontamination with Moringa oleifera and laterite from drinking water resources to safeguard public health at Bongo in Ghana. 2021 Mar 29;6:58-71.

5. Omotayo AO, Olagunju KO, Omotoso AB, Ogunniyi AI, Otekunrin OA, Daud AS. Clean water, sanitation and under-five children diarrhea incidence: Empirical evidence from the South Africa's General Household Survey. Environ Sci Pollut Res Int. 2021 Jul 5;

6. Jordão $\mathrm{CP}$, Pereira $\mathrm{MG}$, Bellato $\mathrm{CR}$, Pereira JL, Matos AT. Assessment of water systems for contaminants from domestic and industrial sewages. Environ Monit Assess. 2002;79(1):75-100.

7. Shukor MY, Anuar N, Halmi MIE, Masdor NA. Near real-time inhibitive assay for heavy metals using achromopeptidase. Indian J Biotechnol. 2014;13(3):398-403.

8. Nag S, Mondal A, Bar N, Das SK. Biosorption of chromium (VI) from aqueous solutions and ANN modelling. Environ Sci Pollut Res. 2017 Aug 1;24(23):18817-35.

9. Blagojev N, Vasić V, Kukić D, Šćiban M, Prodanović J, Bera O. Modelling and efficiency evaluation of the continuous biosorption of $\mathrm{Cu}(\mathrm{II})$ and $\mathrm{Cr}(\mathrm{VI})$ from water by agricultural waste materials. J Environ Manage. 2021 Mar 1;281:111876.

10. Bendezu S, Oyague J, Romero A, García R, Muñoz Y, Escalona N. Chromium adsorption from tannery effluents by activated carbons prepared from coconut shells by chemical activation with $\mathrm{KOH}$ and ZNCL $<$ inf $>2<$ inf $>$. J Chil Chem Soc. 2005;50(4):677-84.

11. Srivastava S, Ahmad AH, Thakur IS. Removal of chromium and pentachlorophenol from tannery effluents. Bioresour Technol. 2007;98(5):1128-32.

12. Zhao C, Yang Q, Chen W, Teng B. Removal of hexavalent chromium in tannery wastewater by Bacillus cereus. Can J Microbiol. 2012 Jan 1;58(1):23-8.

13. Sharmila S, Rebecca Jeyanthi L, Saduzzaman M. Biodegradation of tannery effluent using Prosopis juliflora. Int J ChemTech Res. 2013;5(5):2186-92

14. Huang G, Wang W, Liu G. Simultaneous chromate reduction and azo dye decolourization by Lactobacillus paracase CL1107 isolated from deep sea sediment. J Environ Manage. 2015 Jul 1;157:297-302.

15. Thacker U, Madamwar D. Reduction of toxic chromium and partial localization of chromium reductase activity in bacterial isolate DM1. World J Microbiol Biotechnol. 2005;21(6-7):891-9.

16. Rezaie-Boroon MH, Gnandi K, Folly KT-M. Presence and distribution of toxic trace elements in water and sediments of the southern Togo Rivers watershed, West Africa. Fresenius Environ Bull. 2011;20(7 A):1853-65.

17. Phuong NTK, Khoa NC. Evaluation of heavy metals in tissue of shellfish from Can Gio coastline in Ho Chi Minh city, Vietnam. Asian J Chem. 2013;25(15):8552-6.

18. Mohamed KN. Heavy metals distribution in seabed sediment at Golok Central and Golok Barat gas fields, Sarawak. Bull Environ Sci Sustain Manag. 2014 Dec 3;2(2):48-52.

19. Pathania D. Heavy metals: Sources, toxicity and remediation techniques [Internet]. 2016. 1-310 p. Available from: https://www.scopus.com/inward/record.uri?eid=2-s2.0$85022002221 \&$ partnerID $=40 \& \mathrm{md} 5=\mathrm{e} 10 \mathrm{f} 1 \mathrm{dda} 46896008 \mathrm{cc} 6 \mathrm{~d} 8 \mathrm{bd} 8 \mathrm{f}$ $21 \mathrm{ecf} 83$

20. Kang C, Wu P, Li Y, Ruan B, Zhu N, Dang Z. Estimates of heavy metal tolerance and chromium(VI) reducing ability of Pseudomonas aeruginosa CCTCC AB93066: chromium(VI) toxicity and environmental parameters optimization. World $\mathrm{J}$ Microbiol Biotechnol. 2014; 
21. Degefu DM, Dawit M. Chromium removal from modjo tannery wastewater using moringa stenopetala seed powder as an adsorbent topical collection on remediation of site contamination. Water Air Soil Pollut [Internet]. 2013;224(12). Available from: https://www.scopus.com/inward/record.uri?eid=2-s2.084891491052\&doi $=10.1007 \% 2$ fs 11270-013-1719$6 \&$ partnerID $=40 \& \mathrm{md} 5=2 \mathrm{~b} 19 \mathrm{ba} 77 \mathrm{ed} 50 \mathrm{e} 897 \mathrm{e} 47 \mathrm{e} 1$ dadcde 51822

22. Vankar PS, Sarswat R, Dwivedi AK, Sahu RS. An assessment and characterization for biosorption efficiency of natural dye waste. $\mathrm{J}$ Clean Prod. 2013;60:65-70.

23. Sadiq A, Choubey A, Bajpai AK, Sadiq A, Choubey A, Bajpai AK. Biosorption of chromium ions by calcium alginate nanoparticles. J Chil Chem Soc. 2018;63(3):4077-81.

24. Reyes-Ledezma JL, Uribe-Ramírez D, Cristiani-Urbina E, Morales-Barrera L. Biosorptive removal of acid orange 74 dye by HCl-pretreated Lemna sp. PLoS ONE [Internet]. 2020;15(2). Available from: https://www.scopus.com/inward/record.uri?eid=2s2.0-

$85079081589 \&$ doi $=10.1371 \% 2$ fjournal.pone.0228595\&partnerID $=40 \& \mathrm{md} 5=9 \mathrm{fe} 4 \mathrm{f} 4 \mathrm{ac} 0 \mathrm{bfa} 1 \mathrm{e} 1 \mathrm{bcdc} 87 \mathrm{~b} 815 \mathrm{f} 0 \mathrm{~b} 5 \mathrm{abb}$

25. Waychunas GA, Kim CS, Banfield JF. Nanoparticulate iron oxide minerals in soils and sediments: Unique properties and contaminant scavenging mechanisms. J Nanoparticle Res. 2005;7(4-5):409-33.

26. Rahmani AR, Samadi MT, Noroozi R. Hexavalent chromium removal from aqueous solutions by adsorption onto synthetic nano size zerovalent iron (nZVI). World Acad Sci Eng Technol. 2011;74:80-3.

27. Tripathi DK, Singh VP, Prasad SM, Chauhan DK, Dubey NK. Silicon nanoparticles ( $\mathrm{SiNp}$ ) alleviate chromium (VI) phytotoxicity in Pisum sativum (L.) seedlings. Plant Physiol Biochem. 2015;96:189-98.

28. Motulsky HJ, Ransnas LA. Fitting curves to data using nonlinear regression: a practical and nonmathematical review. FASEB J Off Publ Fed Am Soc Exp Biol. 1987;1(5):365-74.

29. Ridha FN, Webley PA. Anomalous Henry's law behavior of nitrogen and carbon dioxide adsorption on alkali-exchanged chabazite zeolites. Sep Purif Technol. 2009;67(3):336-43.

30. Langmuir I. The adsorption of gases on plane surfaces of glass, mica and platinum. J Am Chem Soc. 1918;40(9):1361-403.

31. Adamson AW. Physical chemistry of surfaces. New York: UMI; 1993. $664 \mathrm{p}$.

32. Radushkevich LV. Potential theory of sorption and structure of carbons. Zhurnal Fiz Khimii. 1949;23:1410-20.

33. Dubinin MM. Modern state of the theory of volume filling of micropore adsorbents during adsorption of gases and steams on carbon adsorbents. Zh Fiz Khim. 1965;39(6):1305-17.

34. Sips R. On the structure of a catalyst surface. J Chem Phys. 1948;16(5):490-5.

35. Toth J. State equations of the solid-gas interface layers. Acta Chim Acad Sci Hung. 1971;69(3):311-28.

36. Brunauer S, Emmett PH, Teller E. Adsorption of gases in multimolecular layers. J Am Chem Soc. 1938;60(2):309-19.

37. Baudu M. Etude des interactions solute-fibres de charbon actif. Application et regeneration. Universite de Rennes I; 1990.

38. Fritz W, Schluender E-U. Simultaneous adsorption equilibria of organic solutes in dilute aqueous solutions on activated carbon. Chem Eng Sci. 1974;29(5):1279-82.

39. Rohatgi

WebPlotDigitizer. http://arohatgi.info/WebPlotDigitizer/app/ Accessed June 2 2014.; 2015.

40. Halmi MIE, Shukor MS, Johari WLW, Shukor MY. Mathematical modelling of the degradation kinetics of Bacillus cereus grown on phenol. J Environ Bioremediation Toxicol. 2014;2(1):1-5.

41. Khare KS, Phelan Jr FR. Quantitative comparison of atomistic simulations with experiment for a cross-linked epoxy: A specific volume-cooling rate analysis. Macromolecules. 2018;51(2):56475 .

42. Burnham KP, Anderson DR. Model Selection and Multimodel Inference: A Practical Information-Theoretic Approach. Springer Science \& Business Media; 2002. 528 p.

43. Akaike H. New look at the statistical model identification. IEEE Trans Autom Control. 1974;AC-19(6):716-23.

44. Kass RE, Raftery AE. Bayes Factors. J Am Stat Assoc. 1995 Jun 1;90(430):773-95.
45. Ross T, McMeekin TA. Predictive microbiology. Int $\mathrm{J}$ Food Microbiol. 1994;23(3-4):241-64.

46. Cai T, Ma M, Liu H, Li J, Hou J, Gong B. Preparation of monodisperse magnetic surface molecularly imprinted polymers for selective recognition of lincomycin hydrochloride in milk. J Liq Chromatogr Relat Technol. 2019;42(13-14):459-67.

47. Gupta GS, Kansara K, Shah H, Rathod R, Valecha D, Gogisetty S, et al. Impact of humic acid on the fate and toxicity of titanium dioxide nanoparticles in Tetrahymena pyriformis and zebrafish embryos. Nanoscale Adv. 2019;1(1):219-27.

48. Liu Z, Gao Y, Jin L, Jin H, Xu N, Yu X, et al. Core-Shell Regeneration Magnetic Molecularly Imprinted Polymers-Based SERS for Sibutramine Rapid Detection. ACS Sustain Chem Eng. 2019;7(9):8168-75

49. Qin H, Cheng H, Long C, Wu X, Chen Y, Hu M, et al. Efficient adsorption of $\mathrm{Hg}(\mathrm{II})$ from aqueous solution by $\mathrm{N}, \mathrm{S}$ co-doped MnFe2O4@C magnetic nanoparticles. Water Sci Technol. 2020;81(6):1273-82.

50. Tan N-D, Lan C, Yin J-H, Meng L, Xu N. Selective Detection of Trace Metronidazole by Using a Magnetic Molecularly Imprinted Polymer-based Fluorescent Probe. Bull Korean Chem Soc. 2020;41(1):60-5.

51. Vicente-Martínez Y, Caravaca M, Soto-Meca A. Simultaneous adsorption of mercury species from aquatic environments using magnetic nanoparticles coated with nanomeric silver functionalized with L-Cysteine. Chemosphere. 2021;282.

52. Baby R, Saifullah B, Hussein MZ. Carbon Nanomaterials for the Treatment of Heavy Metal-Contaminated Water and Environmental Remediation. Nanoscale Res Lett [Internet]. 2019;14(1). Available from: https://www.scopus.com/inward/record.uri?eid=2-s2.0$85075110878 \&$ doi $=10.1186 \% 2$ fs $11671-019-3167$ $8 \&$ partnerID $=40 \& \mathrm{md} 5=\mathrm{b} 895 \mathrm{bb} 2 \mathrm{ee} 5966 \mathrm{fb} 22 \mathrm{c} 84 \mathrm{~d} 2 \mathrm{fc} 67 \mathrm{~d} 975 \mathrm{ec}$

53. Zhang C, Wang W, Duan A, Zeng G, Huang D, Lai C, et al. Adsorption behavior of engineered carbons and carbon nanomaterials for metal endocrine disruptors: Experiments and theoretical calculation. Chemosphere. 2019;222:184-94.

54. Wang Y, Zhao W, Tian X, Song H, Gao R, Tang X, et al. Highefficiency recognition and detection of sulindac in sewage using hydrophilic imprinted resorcinol-formaldehyde resin magnetic nano-spheres as SPE adsorbents combined with HPLC. Chem Eng J. 2020;392.

55. Mueller NC, Nowack B. Nanoparticles for remediation: Solving big problems with little particles. Elements. 2010;6(6):395-400.

56. Li Y, Hong M, Miaomiao, Bin Q, Lin Z, Cai Z, et al. Novel composites of multifunctional Fe3O4@Au nanofibers for highly efficient glycoprotein imprinting. J Mater Chem B. 2013;1(7):1044-51

57. Fernandes T, Soares SF, Trindade T, Daniel-da-Silva AL. Magnetic hybrid nanosorbents for the uptake of paraquat from water. Nanomaterials. 2017 Mar; 7(3):68.

58. Yang K, Wang J, Chen X, Zhao Q, Ghaffar A, Chen B. Application of graphene-based materials in water purification: From the nanoscale to specific devices. Environ Sci Nano. 2018;5(6):126497

59. Barkhordar B, Ghias Aldin M. Comparision of Langmuir and Freundlich equilibriums in $\mathrm{Cr}, \mathrm{Cu}$ and $\mathrm{Ni}$ adsorption by Sargassum. Iran J Environ Health Sci Eng. 2004 Jan 1;1(2):58-64.

60. Ahmad R. Sawdust: Cost Effective Scavenger for the Removal of Chromium(III) Ions from Aqueous Solutions. Water Air Soil Pollut. 2005;163(1-4):169-83.

61. Oguz E. Adsorption characteristics and the kinetics of the $\operatorname{Cr}(\mathrm{VI})$ on the Thuja oriantalis. Colloids Surf Physicochem Eng Asp. 2005 Jan 20;252(2):121-8

62. Tewari N, Vasudevan P, Guha BK. Study on biosorption of Cr(VI) by Mucor hiemalis. Biochem Eng J. 2005 Apr 1;23(2):185-92.

63. Khezami L, Capart R. Removal of chromium(VI) from aqueous solution by activated carbons: Kinetic and equilibrium studies. $\mathrm{J}$ Hazard Mater. 2005 Aug 31;123(1):223-31.

64. Baral SS, Das SN, Rath P. Hexavalent chromium removal from aqueous solution by adsorption on treated sawdust. Biochem Eng J. 2006 Oct 1;31(3):216-22.

65. Ahalya N, Kanamadi RD, Ramachandra TV. Cr (VI) and Fe (III) removal using Cajanus cajan husk. J Environ Biol. 2007;28(4):7659. 
66. Zakaria ZA, Aruleswaran N, Kaur S, Ahmad WA. Biosorption and bioreduction of $\mathrm{Cr}(\mathrm{VI})$ by locally isolated Cr-resistant bacteria. Water Sci Technol. 2007;56(8):117-23.

67. Debnath S, Ghosh UC. Kinetics, isotherm and thermodynamics for $\mathrm{Cr}$ (III) and $\mathrm{Cr}$ (VI) adsorption from aqueous solutions by crystalline hydrous titanium oxide. J Chem Thermodyn. 2008;40(1):67-77.

68. Ucun H, Bayhan YK, Kaya Y. Kinetic and thermodynamic studies of the biosorption of $\mathrm{Cr}(\mathrm{VI})$ by Pinus sylvestris Linn. J Hazard Mater. 2008 May 1;153(1):52-9.

69. Acharya J, Sahu JN, Sahoo BK, Mohanty CR, Meikap BC. Removal of chromium(VI) from wastewater by activated carbon developed from Tamarind wood activated with zinc chloride. Chem Eng J. 2009; 150(1):25-39.

70. Nityanandi D, Subbhuraam CV. Kinetics and thermodynamic of adsorption of chromium(VI) from aqueous solution using puresorbe. J Hazard Mater. 2009;170(2-3):876-82.

71. Khambhaty Y, Mody K, Basha S, Jha B. Kinetics, equilibrium and thermodynamic studies on biosorption of hexavalent chromium by dead fungal biomass of marine Aspergillus niger. Chem Eng J. 2009 Jan 1;145(3):489-95.

72. Kousalya GN, Gandhi MR, Meenakshi S. Preparation of modified chitin for the removal of chromium(VI). Bioremediation J. 2010;14(4):208-18.

73. Liu W, Zhang J, Zhang C, Wang Y, Li Y. Adsorptive removal of $\mathrm{Cr}$ (VI) by Fe-modified activated carbon prepared from Trapa natans husk. Chem Eng J. 2010;162(2):677-84.

74. Dhiwar C, Tiwari A, Bajpai AK. Adsorption of chromium on composite microspheres of chitosan and nano iron oxide. J Dispers Sci Technol. 2011;32(11):1661-7.

75. Shah BA, Shah AV, Singh RR, Patel NB. Reduction of Cr (VI) in electroplating wastewater and investigation on the sorptive removal by WBAP. Environ Prog Sustain Energy. 2011;30(1):59-69.

76. Z.-Q Z, M.-C L, H.-Y Z, S X, X.-J L, J.-Z D, et al. Temperature effect on chromium(VI) removal by $\mathrm{Mg} / \mathrm{Al}$ mixed metal oxides as adsorbents. Appl Clay Sci. 2014;102:246-53.

77. Ahsan MdA, Jabbari V, Islam MdT, Kim H, Hernandez-Viezcas JA, Lin Y, et al. Green synthesis of a highly efficient biosorbent for organic, pharmaceutical, and heavy metal pollutants removal: Engineering surface chemistry of polymeric biomass of spent coffee waste. J Water Process Eng. 2018 Oct 1;25:309-19.

78. Khezami L, Capart R. Removal of chromium(VI) from aqueous solution by activated carbons: Kinetic and equilibrium studies. J Hazard Mater. 2005;123(1-3):223-31.

79. Barkat M, Nibou D, Chegrouche S, Mellah A. Kinetics and thermodynamics studies of chromium(VI) ions adsorption onto activated carbon from aqueous solutions. Chem Eng Process Process Intensif. 2009;48(1):38-47.

80. Zakaria ZA, Zakaria Z, Surif S, Ahmad WA. Hexavalent chromium reduction by Acinetobacter haemolyticus isolated from heavy-metal contaminated wastewater. J Hazard Mater. 2007;146(1-2):30-8.

81. Zhang R, Wang B, Ma H. Studies on Chromium (VI) adsorption on sulfonated lignite. Desalination. 2010;255(1-3):61-6.

82. Hu X-J, Wang J-S, Liu Y-G, Li X, Zeng G-M, Bao Z-L, et al. Adsorption of chromium (VI) by ethylenediamine-modified crosslinked magnetic chitosan resin: Isotherms, kinetics and thermodynamics. J Hazard Mater. 2011;185(1):306-14.

83. Kaprara E, Tziarou N, Kalaitzidou K, Simeonidis K, Balcells L, Pannunzio EV, et al. The use of Sn(II) oxy-hydroxides for the effective removal of $\mathrm{Cr}(\mathrm{VI})$ from water: Optimization of synthesis parameters. Sci Total Environ. 2017 Dec 15;605-606:190-8.

84. Lee C-G, Kim S-B. Cr(VI) Adsorption to Magnetic Iron Oxide Nanoparticle-Multi-Walled Carbon Nanotube Adsorbents. Water Environ Res Res Publ Water Environ Fed. 2016 Nov $1 ; 88(11): 2111-20$.

85. Mahmoud ME, Abdou AEH, Sobhy ME. Engineered nanozirconium oxide-crosslinked-nanolayer of carboxymethyl cellulose for speciation and adsorptive removal of $\mathrm{Cr}$ (III) and $\mathrm{Cr}$ (VI). Powder Technol. 2017 Nov 1;321:444-53.

86. Srivastava S, Agrawal SB, Mondal MK. Synthesis, characterization and application of Lagerstroemia speciosa embedded magnetic nanoparticle for $\mathrm{Cr}(\mathrm{VI})$ adsorption from aqueous solution. $\mathrm{J}$ Environ Sci China. 2017 May;55:283-93. 